\title{
Keskusvirasto vai kehittämiskeskus?
}

\section{- Hallinnon hajauttamiskomitean ehdotusten arviointia kouluhallituksen näkökulmasta.}

\begin{abstract}
Aho, Erkki 1986. Keskusvirasto vai kehittämiskeskus? - Hallinon hajauttamiskomitean ehdotusten arviointia kouluhallituksen näkökulmasta. Aikuiskasvatus 6,2, 9194. - Artikkelissa analysoidaan kouluhallituksen näkökulmasta niitä hallinnon hajautuskomitean esityksiä, jotka koskevat kouluhallitusta. Erityistä huomiota kiinnitetään käytännön hallintotoimiin ja kehittämishankkeisiin, joissa edellytetään valtakunnallista näkemystä.
\end{abstract}

\section{Komitean toimeksianto ja työskentelytapa}

Hallinnon hajauttamiskomitean asettaminen ja toimeksianto perustuivat pääministeri Kalevi Sorsan 4. hallituksen ohjelmaan. Hallitusohjelman mukaan hallintoa hajautetaan siirtämällä tehtäviä ja päätösvaltaa keskushallinnosta aluehallintoon sekä paikallis- ja kunnallishallintoon selvittäen samalla tarve ja mahdollisuudet hallinnon hierarkiatasojen vähentämiseen.

Tiedossani on, että hallitusohjelman tämän kohdan muotoilu vaati aikaa ja neuvonpitoa. Eräillä neuvottelijoilla oli tavoitteena sisällyttää ohjelmaan selkeä kannanotto nykyisen keskusvirastoinstituution hajottamisesta.

Asia nousi uudelleen esille, kun komitean asettamista ryhdyttiin valmistelemaan. Nyt tavoite kirjattiin komitean toimeksiannon Ckohtaan, jonka mukaan komitean tuli valmistella ehdotukset "erityisesti ns. hallinnollisten keskusvirastojen uudelleen järjestämiseksi, yhdistämiseksi tai lakkauttamiseksi sekä näiden ehdotusten toteuttamisen vaatimaksi lainsäädännöksi"'. Komitean asettamista valmisteltiin koko syyskausi -83. Aikaa vei, paitsi toimeksiannon muotoilu, erityisesti sopivan puheenjohtajan löytäminen. Vihdoin keksittiin puolustusministeriöstä kansliapäällikkö, kenraaliluutnantti Aimo Pajunen. Valtioneuvosto asetti komitean 5.1.1984.
Komitea oli kokoonpanoltaan ns. parlamentaarinen komitea. Sen apuna toimi 12-miehinen virkamiehistä muodostettu asiantuntijaryhmä.

Komitea työskenteli n. 2,5 vuotta. Komitean varsin syvällisten muutosehdotusten kohteeksi joutuneen viraston näkökulmasta tarkasteltuna komitean työskentelytapa oli melko itseriittoinen. Kouluhallitusta komitea kuuli kaksi kertaa. Syyskuussa 1985 komitean III jaoston puheenjohtaja Mauri Pekkarinen vieraili virastossa kuullakseen viraston pää- ja ylijohtajaa eräitten tehtäväsiirtoehdotusten johdosta. Toisen kerran komitea kuuli viraston päällikköä huhtikuussa 1986, kun komitean mietintö oli jo lähes luovutusta vaille. Tuossa kuulemistilaisuudessa oli komiteasta paikalla vain puheenjohtaja. Pidin tapaamista lähinnä muodollisuutena.

Komitean III jaoston asettama työryhmä selvitti varsin perusteellisesti kouluhallituksen normiantoa. Työ oli viraston kannalta hyödyllinen ja ajoittui sikäli hyvin, että sen tuloksia voitiin välittömästi hyödyntää 1.8 .1985 voimaan tulleen uuden koululainsäädännön toimeenpanossa.

\section{Komitean ehdotukset}

Komitean mięlestä yhteiskunnan kehitys edellyttää ennen muuta hallinnon kehittämistä siten, että parannetaan hallinnon tuottamien 
palvelujen laatua. Erityisesti tämä koskee kansalaisten kannalta keskeisiä hyvinvointipalveluja kuten koulutusta, terveydenhuoltoa ja sosiaalihuoltoa. Komitean arvion mukaan palvelujärjestelmät ovat rakenteellisesti vakiintumassa ja palvelujen määrä riittävä. Kehittämisen pääkohteiksi on yhä selvemmin nousemassa palvelujen laatu.

Hyvinvointipalvelujen keskeisestä osasta vastaavan kunnallishallinnon toimintakyky ja -valmiudet ovat parantuneet ja palveluyksiköiden edellytykset hoitaa tehtäviään ovat nyt paljon paremmat kuin palvelujärjestelmiä luotaessa. Palvelujen järjestämistä ei tarvitse enää hallinnollisesti ohjata samalla tarkkuudella kuin järjestelmiä luotaessa ja sisäänajettaessa. Kun hyvinvointipalvelujen ohjaaminen kuuluu pääosin valtion keskushallinnolle, voidaan keskushallinnon voimavaroja nyt suunnata palvelujen laadulliseen kehittämiseen.

Komitean ehdotusten ydinsisältö voidaankin tiivistää seuraavasti;

- palvelujen tuottaville yksiköille lisää liikkumavaraa ja harkintavaltaa, ts. tehtävien ja toimivallan reipas siirto keskushallinnosta alaspäin;

- keskushallinnon ja erityisesti keskusvirastojen tehtävissä painopiste palvelujen ja toimintojen laadun kehittämiseen.

Terävöittääkseen sanomaansa komitea ehdottaa, että eräiden ministeriöiden alaiseen keskushallintoon kehitetään keskusvirastoista uusi virastotyyppi, joka on toiminta-ajatukseltaan kehittämiskeskus. Se on asiantuntijaviranomainen, jonka tehtävänäalueena ovat toimialan valtakunnalliset kehittämistehtävät sekä niihin liittyvät alan palvelujen ja muiden toimintojen sisällölliset ja muut laadulliset ohjaustehtävät. Viraston kehittämistyö ja asiantuntemus palvelevat erityisesti asianomaista miniteriötä sekä myös alan alempia viranomaisia ja palveluja tuottavia yksiköitä.

Jotta voimavaroja voitaisiin irroittaa kehittämistyöhön, komitea ehdottaa, että virastosta siirretään;

- valtionosuusasiat lääninhallitukselle,

- rakennusasiat pääosin lääninhallitukselle,

- lainkäyttöpäätökset lääninoikeuksille,

- henkilöstöhallintoasiat ja palveluyksiköitä koskevat hallintoasiat pääosin ao. yksiköille itelleen.

Kehittämiskeskuksen ohjauksen kohteena ovat alan palveluyksiköt, opetushallinnossa siis koulut, aikuisoppilaitokset ja kirjastot.
Palveluyksiköiden taloudellisesta ja hallinnollisesta valvonnasta huolehtivat piirihallintoviranomaiset, opetushallinnossa siis lääninhallitusten kouluosastot, ovat ehdotuksen mukaan suoraan ao. ministeriön alaisia.

Ministeriöllä on oikeus antaa kehittämiskeskukselle toimeksiantoja. Ministerin ohjausvoiman vahvistamiseksi esitetään ministerille pidätysoikeutta kehittämiskeskuksen toimivaltaan kuuluvassa asiassa, jolla on huomattavaa taloudellista ja periaatteellista merkitystä.

Kehittämiskeskukselle tulee varata riittävät taloudelliset ja henkiset voimavarat kehittämis- ja ohjaustehtävien suorittamiseen.

Yleistä päätösvaltaa kehittämiskeskuksessa käyttää johtokunta, jonka puheenjohtajana on kehittämiskeskuksen pääjohtaja ja muina jäseninä osastopäälliköt sekä viisi valtioneuvoton neljäksi vuodeksi kerrallaan määräämää jäsentä. Keskuksen toimintaa johtaa tasavallan presidentin nimittämä pääjohtaja.

Komitea ehdottaa, että ammattikasvatushallitus ja kouluhallitus yhdistetään ja niistä muodostetaan opetusministeriön alainen koulutuksen kehittämiskeskus, joka aloittaisi toimintansa 1.3.1990. Vastaavasti yhdistettäisiin lääkintö- ja sosiaalihallitus sosiaali- ja terveydenhuollon kehittämiskeskukseksi.

\section{Ehdotusten arviointia}

Komitean lähtökohta on oikea. Koulutus on perustavaa laatua oleva hyvinvointipalvelu, yhteiskuntamme on etenemässä kohti syvällisiä taloudellisia, sosiaalisia ja kulttuurisia rakennemuutoksia. Niiden ennakoinnissa, toteuttamisessa ja jälkivaitukusten hoidossa odotetaan koulutuksen tukea. Eikä kysymys ole vain siitä, että koulutus sopeutuisi tai sopeuttaisi muutokseen. Koulutuksen avulla halutaan antaa ihmisille mahdollisuudet vaikuttaa muutoksen suuntaan.

Yhteiskunnan on pystyttävä hallitsemaan tuotantoelämän rakennemuutokset ja vastaamaan kansainvälistymisen haasteeseen kansallinen identiteetti säilyttäen. Yksilön taas on selvittävä ihmisen eri rooleissa tapahtuvista muutoksista psyykkisesti, fyysisesti ja sosiaalisesti terveenä.

Koulutuspalvelujen korkean tason ylläpitäminen edellyttää vakaan ja monipuolisen asiantuntemuksen omaavaa keskushallintoyksikköä. Sen on luotava edellytyksiä sekä jäntevälle ja tulevaisuuteen ojentautuvalle koulutuspolitiikalle ja valtakunnalliselle kehittämistyölle 
että koulujen ja oppilaitosten luovalle toiminnalle.

Hallinnon hajauttamiskomiteassa ei ollut mukana koulutuksen asiantuntemusta. Komitean lähestymistapa on toimeksiannosta johtuen painottunut poliittisesti ja hallintoteoreettisesti. Tästä syystä sen näkemys mm. koulutuksen kehittämisestä on kapea-alainen ja kasvatuksen todellisuutta viipaloiva ja näivettävä. Tämä puute korjaantuu kuitenkin, kun jakovalmistelu siirtyy opetushallinnon käsiin.

Tehtävien ja toimivallan siirtoa koskevat ehdotukset ovat myös oikeasuuntaisia. Uusi koululainsäädäntö on vienyt kehitystä oikeaan suuntaan, mutta kouluhallitus on valmis etenemään hajauttamisen tiellä. Esim. koulutuksen taloustieteen ja koulu- ja kirjastorakentamisen alueella avautuu uusia upeita haasteita, jos osa talous- ja rakentamishallinnon nykyisistä tehtävistä voidaan siirtää piirihallintoon ja kuntiin.

Keskusvirastojen yhdistämistä pidän perusteltuna, mutta olen hyvin tietoinen niistä poliittisista ja henkilöstöpoliittisista ongelmista, joita yhdistämiseen liittyy. Tässä vaiheessa onkin painopiste pantava virastojen yhteistyön kehittämiseen.

Kriittisimmin suhtaudun komitean ehdottamaan uuteen virastotyyppiin, kehittämiskeskukseen. Keskusviraston muuttaminen kehittämiskeskukseksi ei tuo tullessaan mitään etua. Sen sijaan menetetään se valtava henkinen voimavara, jonka yli 100 vuotta toimineessa, perinteistä rikkaassa keskusvirastossa työskentely henkilöstölle ja koko koululaitokselle antaa. Komitean kehittämiskeskukselle kaavailema toiminta-ajatus sopii hyvin myös modernin keskusviraston toiminta-ajatukseksi. Varsinkin kun virastolla komiteankin ehdotuksen mukaan on itsenäinen päätösvalta koulutuksen kannalta keskeisissä asioissa, kuten opetussuunnitelmat, oppimateriaalit, arviointi- ja valintajärjestelmät. Kyllä me pystymme karistamaan harteiltamme perinteen kielteiset rasitteet ja uudistumaan ajan vaatimusten mukana.

Toinen syy, miksi vastustan uutta virastotyyppiä, liittyy sen asemaan hallinnossa. Komitean ehdotus kuroo todennäköisesti asteittain viraston irti linjahallinnosta, joka alkaisi yhä useammassa asiassa kulkea suoraan ministeriöstä lääninhallituksiin.

Tähän viittaa sekin, että komitea asettaa selväksi tavoitteeksi ministeriöhallinnon vahvistamisen ja esittää ministerin pidätysoikeuden käyttöönottoa keskusviraston keskeisillä tehtäväalueilla. Tavoitteena on kansanvaltaisen valvonnan lisääminen. Paperilla pidätysoikeus näyttää viattomalta. Se saattaa houkutella, koska se on hallinnollisesti helpompi ja poliittisesti näyttävämpi kuin jäntevään linjanmäärittelyyn perustuva ohjaus, mutta se sopii huonosti pitkäjänteistä kehittämistyötä tekevän, lasten ja nuorten kasvatuksesta vastaavan hallinnon ohjaamiseen. Kansanvallan, mutta myös asiantuntevan päätöksenteon kannalta ehdotuksen tekee arveluttavaksi se, että ministerillä ei ole aikaa eikä mahdollisuuksia tutkia keskusviraston päätösluonnoksia perusteluineen. Sen tekee joku yksittäinen virkamies, jonka käsiin kasaantuu tällöin riittävästi täysin kontrolloimatonta valtaa.

Olen vakaasti sitä mieltä, että kehittämistyötä on jatkettava keskusvirasto-mallin pohjalta. Jos esteenä on se, ettei keskusvirastoon voida nimittää komitean ehdottamaa johtoelintä, johtokuntaa, on mahdollista kehittää koulualan keskusvirastoon soveltuva laajennettu kollegio, joka turvaa tarvittavan lisäasiantuntemuksen periaatteellisesti tärkeitä ratkaisuja tehtäessä.

\section{Mitä tapahtuu jatkossa, vai tapahtuuko mitään?}

Komitea ehdottaa erittäin nopeaa ehdotuksensa toimeenpanoa. Valtioneuvoston tulisi antaa välittömästi opetusministeriölle toimeksianto jatkovalmistelun käynnistämisestä. Siinä sekä valtion ensi vuoden tulo- ja menoarvion yleisperusteluissa tulisi autorisoida komitean ehdotusten yleislinja. Uuden viraston, koulutuksen kehittämiskeskuksen tulisi aloittaa toimintansa 1.3.1990. Komitea pitää valmisteluaan niin perusteellisena, ettei varsinaista selvitystyötä enää tarvita.

Nyt on kuitenkin sovittu, että komitean mietintö tulee lausunnolle myös keskusvirastoihin. Mielenkiintoista ja jatkon kannalta varsin ratkaisevaa on, antaako valtioneuvosto opetusministeriölle toimeksiannon ennen kuin lausunnot on saatu, ja millaiset tavoitteet valtioneuvosto jatkotyölle asettaa. Päätöksen on synnyttävä pian, sillä muuten linjaa ei ehditä autorisoida vuoden 1987 TMAE:ssa. Jos ratkaisu lykkäytyy budjetin antamisen jälkeiseen aikaan, saattaa koko asia jäädä vaalien jalkoihin. Ja sitten onkin taas uusi eduskunta, uusi hallitus ja sillä uusi ohjelma!

Keskusvirastojen harras toivomus ja selkeä kanta on, että jokin ratkaisu on saatava aikaan mahdollisimman pian. Jatkuva epävarmuus 
vie virastoilta työmotivaation ja jäädyttää virastojen omat ehdotukset hallinnon kehittämiseksi. Valtakunnalla ei ole varaa lamauttaa keskeistä palvelusektoria hoitavaa hallintoa.

Tämä on tajuttava niidenkin poliittikkojen, joita näyttää jääneen vaivaamaan se, ettei yhtään keskusvirastoa saatu lakkautettua.

Keskusvirastot vastaavat tälläkin hetkellä maamme koululaitoksen kehittämisestä. $\mathrm{Ne}$ tarvitsevat välittömästi komitean ehdottamia lisävoimavaroja; kunnolliset palvelusuhteen ehdot henkilöstölle, varoja tutkimukseen, kokeiluun, henkilöstökoulutukseen ja tiedotustoimintaan. Jos ja kun poliittinen päättäjä on todella huolissaan koulutuspalvelujen tasosta, se voisi ja sen pitäisi turvata välittömästi valtakunnallisen kehittämistyön edellytykset. 